\title{
ВИКОРИСТАННЯ АВС - АНАЛІЗУ ПРИ ПЛАНУВАННІ ВИРОБНИЦТВА ПРОДУКЦЇ̈
}

\author{
Леонтьсва I.O. ${ }^{1}$ \\ ${ }^{1}$ Одеська національна академія харчових технологій, Одеса \\ Copyright (C) 2014 by author and the journal "Automation technological and business - processes". \\ This work is licensed under the Creative Commons Attribution International License (CC BY). \\ http://creativecommons.org/licenses/by/4.0/
}

\begin{abstract}
Анотація
Розглядається значення функції планування на базі процесного підходу, виділення основних бізнес процесів на підприсмстві; застосування методу АВС - аналізу на прикладі фармацевтичного підприємства при плануванні виробництва продукції, приведення відповідних розрахунків та розподілення товарів на категорії A, В, С; обгрунтування доцільності автоматизації розрахунків АВС - аналізу в інтелектуальних алгоритмах програмного забезпечення, вирішення задачі планування виробництва шляхом простежування тенденції реалізації товару за певний період часу; управління товарним асортиментом; забезпечення формування збалансованого планування виробництва, 3 урахуванням обороту і прибутковості кожної товарної позиції; планування обсягів виробництва на основі проведеного аналіз. Показано, що допомогою методу АВС - аналізу можна структуровано та більш точно відтворити і надати відповідну інформацію в різноманітних розрізах (за кліснтами, препаратами тощо), що, у свою чергу, дозволить об'сктивніше оцінювати ефективність процесів, які відбуваються на підприсмстві, а головне виявляти приховані резерви зниження витрат і приймати обгрунтовані рішення щодо виключення малорентабельних видів діяльності. Визначення конкретних переваг у результаті використання АВС - аналізу, а саме: автоматичне відображення проведеного АВС - аналізу має велику візуальну інформативність, оскільки не потребує глибинного вивчення додаткових даних, що дас швидке сприйняття результатів та прийняття управлінських рішень («миттсвий наглядний аналіз») щодо планування виробництва, а також приводить до підвищення ефективності виконання трьох найважливіших функцій: планування, контролю та управління (саме ці функції виступають у ролі «двигуна» розвитку бізнесу).
\end{abstract}

\section{Abstract}

We consider the importance of planning functions based on the process approach, the selection of core business enterprise processes; of the method ABC - analysis on the example of the pharmaceutical enterprise in planning production and bringing relevant calculations and distribution of products in categories $\mathrm{A}, \mathrm{B}, \mathrm{C}$; rationale automate calculations ABC - analysis of intelligent software algorithms that solve the problem of production planning by tracking trends in sales of goods for a certain period of time; management product range; ensuring formation of balanced production planning, including turnover and profitability of each heading; planning of production on the basis of the analysis. It is shown that the method ABC - analysis can be structured and accurately reproduce and provide relevant information in different sections (for clients, drugs, etc.), which, in turn, will objectively evaluate the effectiveness of the processes taking place in the enterprise, and most importantly detect hidden reserves to reduce costs and make informed decisions to exclude unprofitable activities. Definition of concrete benefits resulting from the use of $\mathrm{ABC}$ - analysis, namely the automatic display conducted $\mathrm{ABC}$ - analysis has a great visual informative because it does not require in-depth study of additional data that provides quick results perception and decision-making ("a visual instant analysis") for planning production and leads to an increase in the efficiency of the three major functions: planning, monitoring and management (these functions act as "engine" of the business).

\section{Ключові слова}

Процесний підхід, планування виробництва,обсяг реалізованої продукції, АВС-аналіз. 
Вступ

У загальному значенні планування - це визначення мети, розробка стратегії і тактики дій, а також розподіл ресурсів між основними заходами, що входять в план.

Значення планування для підприємства дуже велике: за допомогою детально розроблених планів, заснованих на реальних фактах діяльності підприємства, аналізу діяльності у попередніх роках, керівник зможе ефективно управляти господарською діяльністю підприємства і впливати на результати за підсумками фінансового року. Планування на підприємстві дозволяє повною мірою враховувати вплив змін зовнішнього середовища, розробляти програми протидії негативним факторам і програми використання сприятливих можливостей для підприємства, а також програми альтернативних стратегій у випадку настання або ненастання певних ризиків.

Все це робиться для мінімізації негативних факторів і максимального використання сприятливих обставин. Тому можна сказати, що планування виробництва, на прикладі фармацевтичного підприємства сьогодні ніяк не втратило свого значення, а дещо змінило його. В умовах активної конкуренції і складною зовнішнього середовища ефективне управління компанією можливе тільки завдяки використанню планів господарської діяльності на основі автоматизованої системи планування на підприємстві. Плани орієнтують роботу всіх підрозділів і відділів підприємства на спільну цілеспрямовану роботу для досягнення поставленої перед підприємством цілі.

Планування на підприємстві також дозволяє, враховуючи діяльність конкурентів, розробляти ефективні прийоми протидії, для того, щоб домогтися нових конкурентних переваг. Адже, при правильному використанні сучасних та актуальних методів планування будь-яка компанія може зміцнити своє становище на ринку.

\section{Основна частина}

В ході планування складається програмний документ, програма здійснення бізнес-операцій, дій підприємства, що містить відомості про підприємство, товар, його виробництво, ринках збуту, маркетингу, організації операцій та їх ефективності.

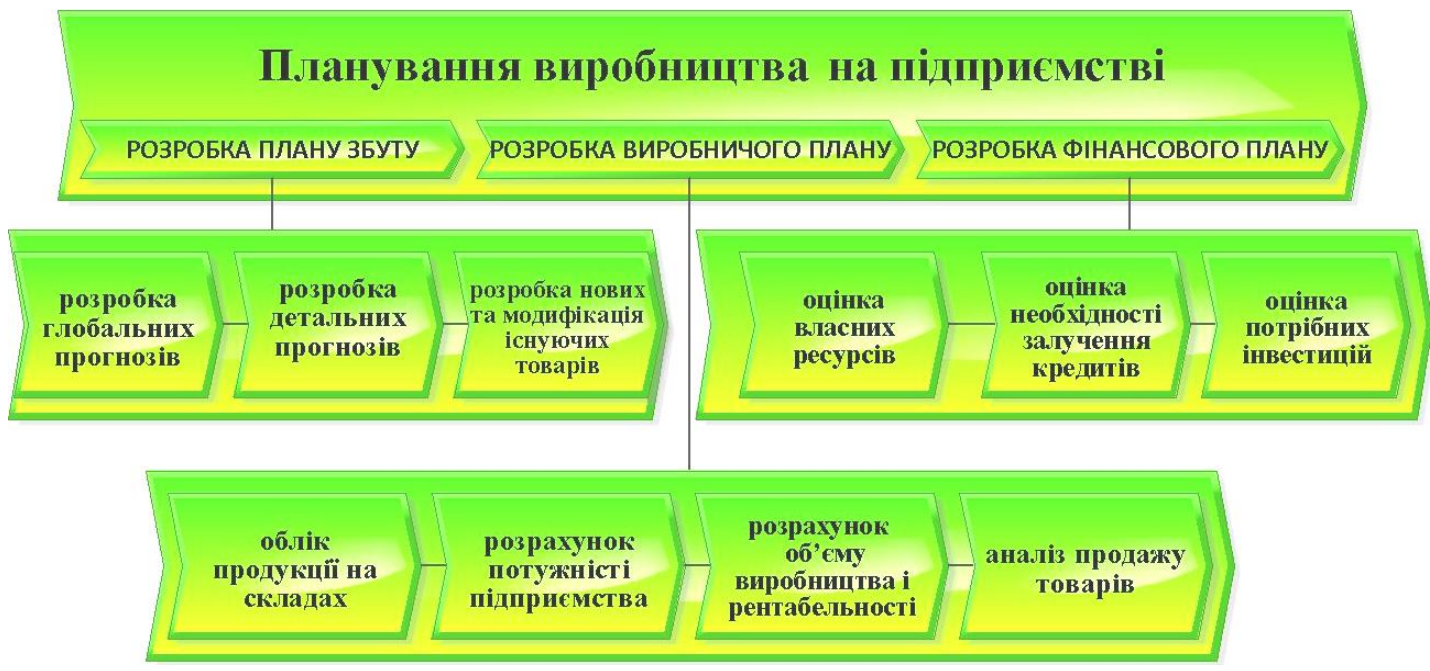

Рис.1. Схема планування виробництва на базі процесного підходу.

Оптимізації і найкращому узгодженню планів сприяє процесний підхід, коли планування збуту, виробництва та фінансів розглядається як єдиний бізнес-процес. У цьому випадку інтегратором збуту та виробництва (організатором і виконавцем планування i, відповідно, основним координатором обсягів виробництва, поставок і величини запасів продукції на складах по всьому асортименту підприємства) стає підрозділ логістики.

3 рис.1 видно, що план виробництва продукції опирається на дані по всім параметрам продукції. Одними 3 найважливіших даних являється аналіз продажу товарів, який здійснюється за допомогою АВС- аналізу. ABC - аналіз є одним з універсальних методів, який направлений на аналіз і управління асортиментом товарів. Доцільність застосування та суть АВС - аналізу уже відома на прикладі деяких вітчизняних підприємств [1]. I як правило, методика АВС - аналізу базується на концепції категорійного менеджменту, який передбачає формування асортименту підприємства на основі вивчення потреб і попиту споживачів, тому зростає роль ефективності управління товарними запасами на складах, що можливо здійснити за допомогою методу АВС - аналізу. 


\section{7 СТУДЕНТСЬКА НАУКА}

У практиці застосування АВС - аналізу необхідне для правильного формування груп товарів, які приносять найбільшу виручку та формують прибуток, а також для того, щоб уникнути перенасичення асортименту в тих товарних групах, які мають маленький прибуток і малу націнку. АВС - аналіз дозволить виділити пріоритетні, базові та унікальні категорії товарів, що сприятиме розвитку та зміцненню позицій певних товарів.

За допомогою методу АВС - аналізу можна структуровано та більш точно відтворити і надати відповідну інформацію в різноманітних розрізах (за клієнтами, препаратами тощо), що, у свою чергу, дозволить об'єктивніше оцінювати ефективність процесів, які відбуваються на підприємстві, а головне виявляти приховані резерви зниження витрат і приймати обгрунтовані рішення щодо виключення малорентабельних видів діяльності.

Отже, для підприємства завданням являється проведення АВС - аналізу для подальшого планування виробництва лікарських препаратів. Проведемо відповідні розрахунки, скориставшись даними зі звіту продажу лікарських препаратів за певний проміжок часу.

Спочатку находимо частку реалізованого препарату,\% - позначимо N, що і буде критерієм цінності даного препарату та його показником для віднесення до тієї чи іншої групи товарів (А, В або С). Якщо N $\leq 8 \%-$ категорія $\mathrm{C}, 8 \%<\mathrm{N} \geq 20 \%$ - категорія $\mathrm{B}, \mathrm{i} \mathrm{N}>20 \%$ - категорія А.

Виручка реалізованого товару = Кількість проданого препарату*Ціну за одиницю товару. Загальна виручка - це сума виручки по кожному препарату окремо.

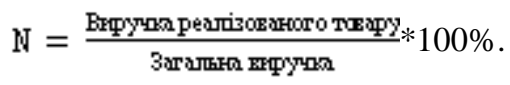

Наприклад, розрахуємо частку N Аміксину за поточний Загальна виручка по всіх товарах за місяць становить 54310,62 грн. Ціна, за одиницю препарату Аміксин становить 20,46 грн. Кількість проданого препарату за місяць становить 600 шт. Виручка від Аміксину=20,46*600=12276 грн./міс.

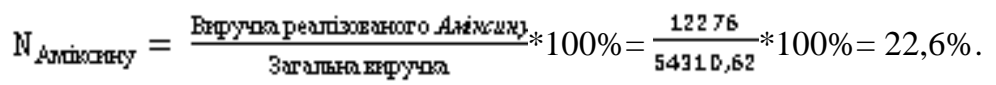

Тобто, препарат має достатньо великий попит та значну цінність та відноситься до групи А

Таким чином, даний алгоритм дає змогу автоматично розраховувати частку кожного 3 препаратів та розподіляє їх по відповідним групам. I у результаті відображає графік проведеного АВС - аналізу, що для менеджера дає реальне обгрунтування для прогнозу подальшого планування виробництва товарних груп.

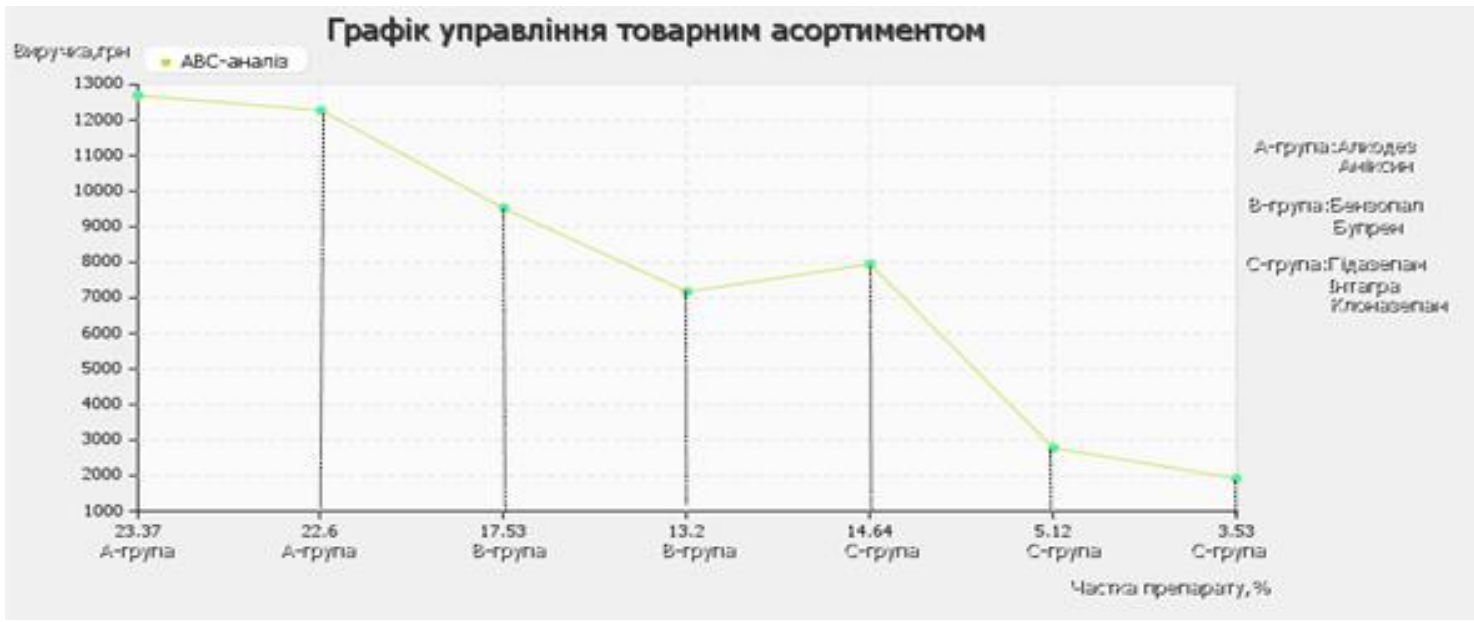

Рис. 2 Графік результату АВС - аналізу.

Результат проведення АВС - аналізу показав, що найбільш цінними являються препарати: Алкодез та Аміксин - група А. Група В: Бензопал та Бупрен - вони є базовими препаратами, основою усього асортименту. Група С: Гідазепам, Інтагра, Клонозепам - найменш цінні. На рис. 2 показано діапазон виручки по кожній групі товарів за певний проміжок часу. 


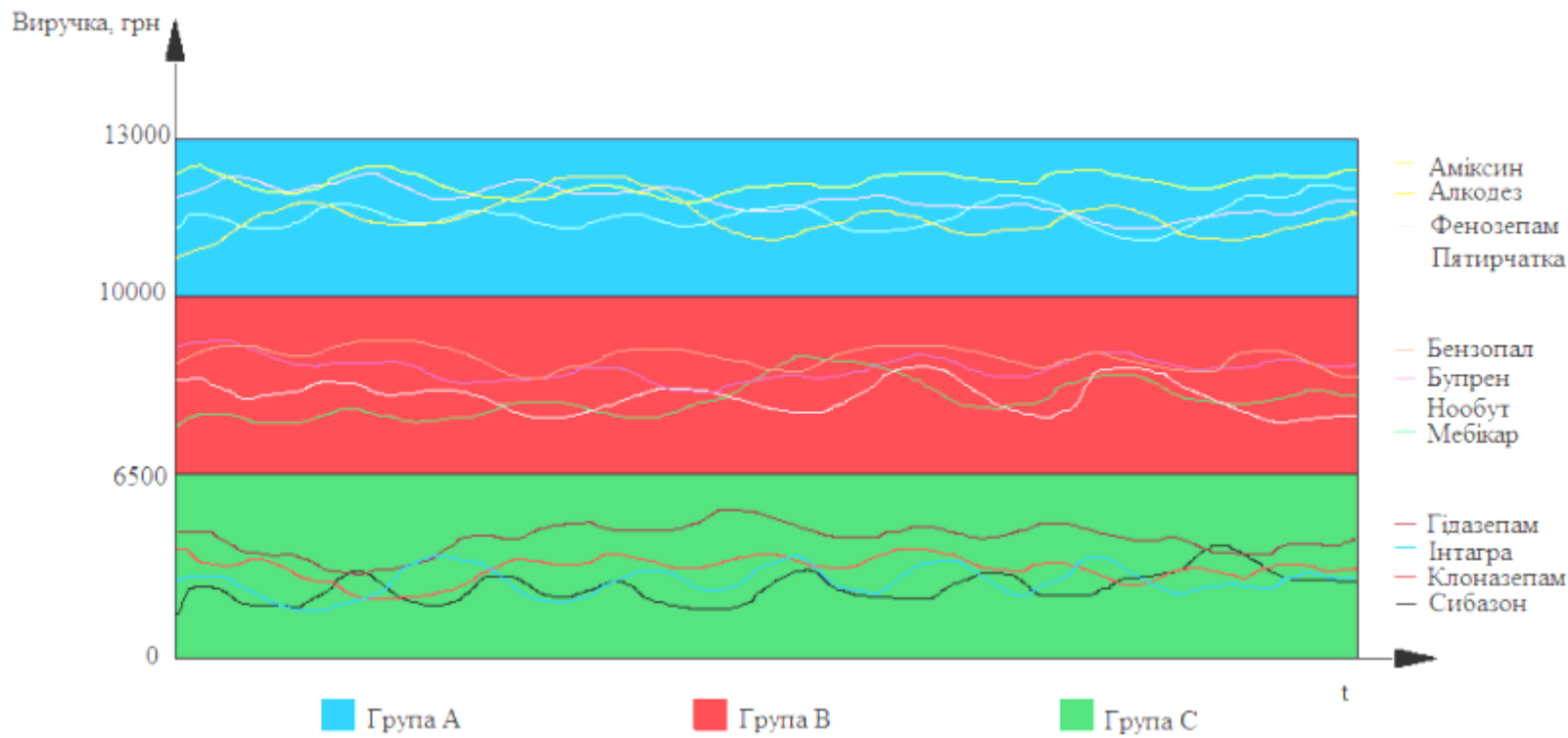

Рис.3 Доля виручки, яку приносить кожна $з$ груп за певний період часу.

Якщо простежувати коливання кривої АВС - аналізу довгий період (від 3-4-х місяців), то за весь час буде визначено таке: (рис.3)

1. збільшились продажі товарів групи А (об’єм продажу зріс від 6\% до 14\%, частка продажу збільшилась від $19 \%$ до $23 \%$ );

2. стабільні продажі групи В (об’єм продажу збільшився з 20 до 22\%, частка товарної групи в загальному обсязі збільшилась від $11 \%$ до 14\%);

3. знизились продажі в товарній групі С (обсяг продажу знизився 374 до 64\%, знизилась частка товарної групи з 7\% до 3\%).

\section{Тенденція реалізації товару за певний період часу}

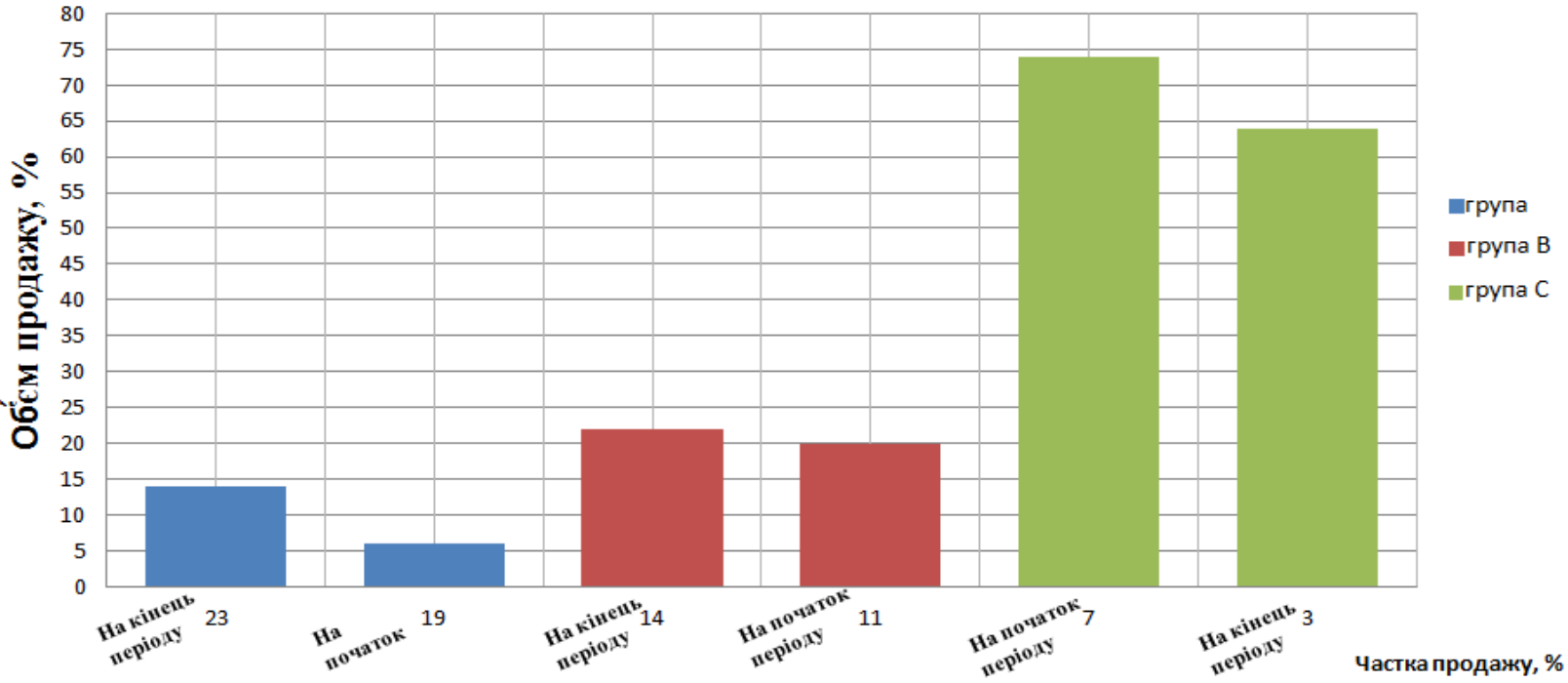

Рис.4 Тенденція реалізації товару за певний період часу

В рамках запропонованих стратегій по кожній товарній групі можна приступати до поточного планування виробництва. 


\section{7 СТУДЕНТСЬКА НАУКА}

1. Вироби групи А знаходяться на стадії стрімкого зростання. Щоб зайняти максимально можливу частку на ринку, необхідно випустити більше різних модифікацій товарів цієї групи (збільшити виготовлення на 4\% $-5 \%)$

2. Для препаратів В можна рекомендувати стратегію зростання разом з ринком, тобто підтримку інвестицій на рівні минулого року щодо обсягу продажу (збільшення виготовлення 1-2\%, тим самим підтримання позицій групи);

3. Препарати С втрачають позиції. Продукт, який поступово переходить у стадію спаду, можна «оживити», вдаючись до його модифікації (диференціації), ребрендингу і часткового репозиціонування, реклами та оновлення (зміна виробництва).

Конкретизуємо та вирішимо задачу планування об'ємів виробництва продукції в асортименті, тобто використаємо усі дані АВС - аналізу, в своєму програмному забезпечені запропоную об'єктивний інтелектуальний алгоритм визначення обсягів виробництва $y_{i} \leq x_{i} \leq d_{i}$, де $y_{i}$ - мінімальна партія (обсяг) виробництва і-го виду продукції (за статистикою періоду, що показав найгірший показник продажу); $d_{i}$ - максимальний обсяг попиту, розрахований на основі оборотності продукту (за статистикою періоду, що показав кращий показник продажу); $x_{i}$ обсяг запланованого виробництва продукції і-го виду, з урахуванням коригування за результатами аналізу.

Група А: $6 \% \leq 10 \% \leq 14 \%$; збільшено обсяг виробництва на $4 \%$;

Група В: $20 \% \leq 21 \% \leq 22 \%$; збільшено обсяг виробництва на $1 \%$;

Група С: $64 \leq 64 \% \leq 74 \%$; обсяг виробництва залишено незмінним та підлягає модифікації.

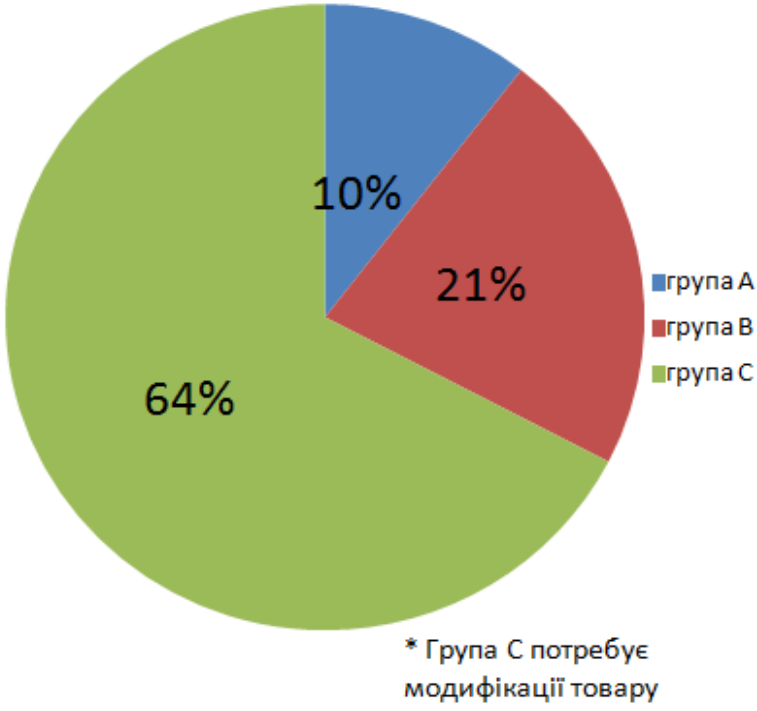

Рис.5. Діаграма планування обсягів виробництва на основі проведеного аналізу.

\section{Висновки:}

Основною метою АВС - аналізу є забезпечення формування збалансованого планування виробництва, 3 урахуванням обороту і прибутковості кожної товарної позиції.

Результати дослідження показали: правильне використання процесного підходу до виробництва, застосування інструменту АВC - аналізу, а також автоматизоване програмне забезпечення для використання таких інструментів дає конкретні переваги:

- $\quad$ важливим $є$ максимальне скорочення часу на рутинну працю по розрахунках, тим самим можливість його використання з більшою користю, а також виключення фактору людської помилки;

- автоматичне відображення проведеного АВС - аналізу має велику візуальну інформативність, оскільки не потребує глибинного вивчення додаткових даних, що дає швидке сприйняття результатів та прийняття управлінських рішень («миттєвий наглядний аналіз») щодо планування виробництва;

- підвищення ефективності виконання трьох найважливіших функцій: планування, контролю та управління (саме ці функції виступають у ролі «двигуна» розвитку бізнесу). 


\title{
ㄱ СТУДЕНТСЬКА НАУКА
}

Література

1. Івахів Ю., Спільник I. Метод АВС-аналізу: доцільність застосування. Економічний аналіз. Вип. 3(19). 2008p.;

2. Дзюба О.Д., Метод АВС - аналізу витрат торгівельного підприємства: теорія та практика застосування, 2011 p.;

3. Пічугіна Т.С., Оцінки ефективності асортиментної політики підприємств роздрібної торгівлі на основі використання АВC- аналізу,2012p.

References

1. Ivakhiv Yu, Accomplice I. Method ABC analysis: feasibility of application. Economic Analysis. Vol. 3(19). 2008;

2. Dziuba O.D., ABC method - cost analysis of commercial enterprises: the theory and practice of, 2011;

3. Pichugin T.S., evaluating the effectiveness of policies assortment of retailers on the basis of analysis ABC, 2012.

Науковий керівник: Жигайло О.М., к.т.н., доц., доцент кафедри автоматизації виробничих процесів Одеської національної академії харчових технологій.

\section{ДОСЛІДЖЕННЯ МОЖЛИВОСТЕЙ ПІВИЩЕННЯ ЕФЕКТИВНОСТІ СИСТЕМИ АВТОМАТИЧНОГО УПРАВЛІННЯ ТЕМПЕРАТУРНИМ РЕЖИМОМ ТЕХНОЛОГІЧНОГО ПРОЦЕСУ ОЧИЩЕННЯ ВОДИ ДЛЯ ВИРОБНИЦТВА ЛІКІВ ЗА РАХУНОК УДОСКОНАЛЕННЯ ЇЇ СТРУКТУРИ}

Щегловський O. $^{1}$

${ }^{1}$ Одеська національна академія харчових технологій, Одеса

Copyright $(\mathcal{O} 2014$ by author and the journal "Automation technological and business - processes". This work is licensed under the Creative Commons Attribution International License (CC BY). http://creativecommons.org/licenses/by/4.0/

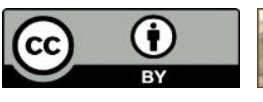

\begin{abstract}
Анотація
У статті розглядається доцільність ускладнення алгоритмів розрахунку керуючих дій для управління технологічним процесом очищення води для виробництва ліків. Наведений опис технологічного процесу водопідготовки та його основних принципів пов'язаних із температурними режимами, дослідження щодо підвищення якості регулювання температури підготовленої води. Метою дослідження була розробка такої системи автоматичного регулювання, що забезпечує знаходження температури підготовленої води у межах встановлених технологією регламентних зон. Для розробки системи автоматичного регулювання та дослідження показників їі роботи був використаний метод імітаційного цифрового моделювання. Була розроблена модель об'єкту управління з урахуванням динамічних та статичних властивостей каналу реального об'єкту управління. Дослідження проводилося у два етапи: розробка та дослідження систем автоматичного регулювання (базової структури 3 використанням ПІД-регуляторів та підвищеної динамічної точності за допомогою додаткових динамічних ланок, що забезпечують інваріантність системи до шкідливого впливу перехресного каналу в об'єкті управління), розробка та дослідження системи автоматичного управління, що гарантує знаходження температури у межах регламенту. Моделювання
\end{abstract}

